\title{
The Macroeconomics of Food insecurity and Food Price in Ethiopia: Bayesian VAR Analysis
}

\author{
Ahmed Alkader Hassen \\ Lecturer, Department of Economics, Wollo University, Dessie, Ethiopia \\ ahmedalkader9@gmail.com or ahmddat@yahoo.com
}

The general objective of the study is to analyze food insecurity determinants mainly related to food price at macro level. The study used a time series data from the year 1988 quarter one to 2018 quarter four. Our empirical finding on the macroeconomic model show the short term consequence of food price change is positive with food security (negative with food insecurity). The long term consequence of food price change is, however, negative with food security (positive with food insecurity) at macro level. From the variance decomposition, it can be learned that the speed by which the undernourished people decrease in number in the short term because of the inflation happened is higher than the speed by which the number of undernourished people increase in the long run. At macro level, concern should be made to the supply side for food security improvement.

Keywords: Food security, Food inflation, Bayesian VAR

\section{INTRODUCTION}

The subsistence farming system and recurrent natural disaster has been affecting the Ethiopian agriculture output. The recurrent drought in Ethiopia has reduced food production which created food shortage in the country. A report by FAO (2015) shows that the drought occurred in 2015 reduced agricultural production which has led to more than 27 million people became in shortage and 18.1 million require food assistance. Food insecurity situation in Ethiopia has worsened after the country smashed by the 2015 El Niño drought which led to more than 27 million people in food shortage.

Food inflation rate increased by 11.8 percent in 2019 as compared to the one observed a 
year ago and the non-food inflation rate increased by 13.3 percent in the same year (CSA, 2019). The sharp rise in food price which is the largest in Sub Saharan Africa especially the price of cereals in the post $2002 / 3$ period, which put many people in to food poverty. This is because food expenditures constitute $57 \%$ of household expenditures (see Geda and Tafere, 2011; Cochrane, 2017). The final 2019 CSA statistics also shows that the headline inflation has reached a record high rate of 17.9\% in August 2019.

The overall all inflation rate in 2009 for Amhara regional state was $27.8 \%$ (which is slightly higher than the countries average) in a yearly base compare to the baseline year 2006. The highest CPI was registered in September and October in the same year (In September 2009 for example the food price index increase by $121 \%$ compared to the base line year) (CSA,2009). Durevall et al., (2010) consider world prices in the international market and the supply side are responsible for this high rate of food price inflation. Hence, in this paper the relationship between food price and food security situation of Ethiopia and the factors affecting local and national food price.
The Economic theory of inflation states that inflation hurts lenders and fixed income earners. The poor gets poor when there is high rate of inflation. That is why Fischer and Easterly (2001) interpreted the statement "inflation is a cruelest tax of all" as the effect of inflation is negative for poor people than the rich. In Ethiopia, food price on the rise, pushing millions in to deeper poverty. Nowadays, the cost of goods and services are on the rise which pushes most people in to poverty.

There is no consensus on why Ethiopia experienced such dramatic food insecurity rises. While much literature documented that climatic and land pressures, rapid population growth, and political unrest and armed conflict as the most contributing factors for food insecurity in Ethiopia, others like Cochrane (2017) added that food price inflation is significance challenges related to food insecurity. The country statistics agency reports that the price of food items are near to double in the year 2018/19 to 2019/20. Studies find that exchange rate, and international food and goods prices, agricultural supply shocks, markup prices, money growth and inflation inertia causing large deviations from long-run price trend may cause food price inflation in Ethiopia (See among others Durevall et al., (2010); 
Durevall et al. 2013; Geda and Tafere, 2011 and Denbel 2016).

Birhane et al. (2014) explain that the main reasons reported for inadequate food consumption in Ethiopia was food shortages due to high food price. However, these authors used the cross-sectional research design, which makes unable to investigate causal links between rising food prices and food insecurity situations. Moroda et al. (2018) also analyze the source of food insecurity in Ethiopia at micro level, however, price of local foods was not taken as an explanatory variable which has a

\section{REVIEW LITERATURE}

Although food security is a big challenge in developing countries, the number of people under food security has reduced for the last decade. The statistics suggests that $25 \%$ of the people in Ethiopia is below food poverty line (Samia et al., 2014). Undiversified livelihood conditions and lack of agricultural production due to low input and low output and bad weather condition has caused food poverty as a major macroeconomic problem (Devereux, 2000). Birhane et al., (2014) suggested that food price inflation as a cause of food poverty at micro level. As a result some recommended that decreasing the significance effect on the result. The paper is motivated by the following issues. While the food price is rising to make every one poor and while proper quantification of the link between food price and food insecure households is important for policy making and forecasting, there is a no research related to the connection between food insecurity and food prices at macro level. As the researcher knowledge, this paper is the first in its type to incorporate, develop and observe macro level factors of food insecurity and proper quantification of the link between food insecurity and food prices in Ethiopia.

dependency ratio and land holding can significantly improve household welfare as a result of food price inflation (Eric et al., 2018).

The empirical literature on the macroeconomics of food security is not available in Ethiopia. Food security issue is one of the basic macroeconomic problem of developing countries. As a result the government of Ethiopia has been following a special national program called: the New Coalition for Food Security (NCFS) by incorporating the large productive safety net program (MoARD, 2009). In Ethiopia, the number food insecure people have showed reduction after 2001, however, it has 
increased continuously since 2018 (WB, 2018) as the population growth is still high (Anderson et al., 2015). The figure below shows the number of food insecure people as a percent of total population from $1988 \mathrm{q} 1$ $2018 \mathrm{q}^{1}$.

Figure 1: Percentage of food insecure people in Ethiopia form the total population

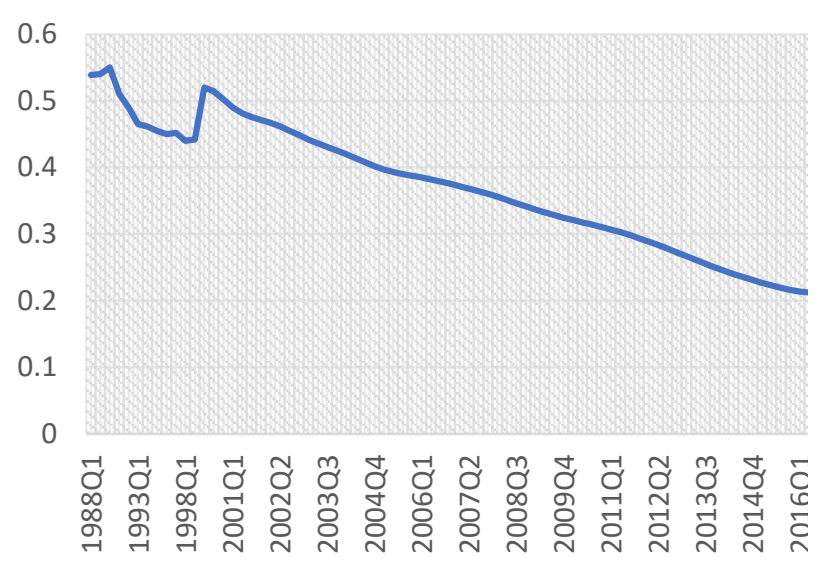

Source: World Bank (2018)

The empirical literature on food security has been documented and generalization has been made at different prospective. Some states change in the level of food security with related to climate change, land degradation, irrigation and so on (Cochrane, 2017). Others still conclude that food price change is a major source of food insecurity (Birhane et al., 2014). Social services has been also mentioned as a source of food poverty. For example poverty of water (Hadley \& Freeman, 2016), mental disorder and distress (Mulusew et al., 2015), lack of and or inadequate access to

\footnotetext{
1 " $q$ " stands for quarter period.
}

school services (Tefera et al., 2011). However, other authors has criticized the above generalizations. One of the criticism is that the conclusion made with these researches on the correlation between food security and nutrition and a set of explanatory variables have not used the correct methodology to discuss the issue. Moreover, the indicators used to classify people in to food insecurity is not consistent which may result inconsistency conclusions and generalizations (Watson et al., 2011). As a result Watson et al., (2011) recommend that different researches should use a specific identical measurement which can be endorsed by the government or the Food and Agricultural Organization (Maxwell et al., 2014). Consequently, the result and conclusion scan be reliable and trustworthy.

\section{METHODOLOGY}

\subsection{Model Specification}

In this model, it is assumed the food demand and food supply determines the price of goods and services. The aggregate food supply may come from total production(Y), or in may come from be imported (M) or can be in the form of food aid (Aid). Total output is consists the elements of on farm consumption of farmers and marketed surplus from agricultural production, Industrial products of food and non-food 
items and service products related with road ,education, health investments. The amount of food supply can be also affected by the amount of food aid or the amount of imported food and merchandise items. For example, the amount of agricultural imports may affect the supply of foods. The price of food $\left(P_{f}\right)$ and non-food items $\left(P_{n f}\right)$ are other factor included in the model. Their size has often been considerable and served ease the domestic demand.

$S_{f}$ $=Y_{t}^{\omega_{1}} \mathrm{Aid}^{\omega_{2}} P_{f}^{\omega_{3}} P_{n f}{ }^{\omega_{4}} M_{t}^{\omega_{5}} I P^{\omega_{6}} W^{\omega_{7}}$ Pins $^{\omega_{8}} \ldots 1$

The supply of food is assumed to be exogenous determined by weather condition $\left(W_{t}\right)$, international prices $(I P)$ and institutional factors that may include the land tenure system and political stability (Pins) (see Geda and Tafere, 2008). Hence, these variables are considered as exogenous variables which would be determined outside of the model. The Supply of food is restructured as:

$S_{f}$ $=Y_{t}{ }^{\omega_{1}} M_{t}{ }^{\omega_{2}} \mathrm{Aid}_{t}{ }^{\omega_{3}} P_{f t}{ }^{\omega_{4}} P_{n f t}{ }^{\omega_{5}}$ Transforming equation 1 using logarithm,

$$
\begin{gathered}
S_{f}=\omega_{1} Y_{t}+\omega_{2} M_{t}+\omega_{3} A_{i d}+\omega_{4} P_{f t} \\
+\omega_{5} P_{n f t} \ldots \ldots \ldots 3
\end{gathered}
$$

Aggregate demand for food is determined by price of foods (domestic and international prices), total income, excess money supply, total population (see Geda and Tafere, 2008). These authors have missed the big concept of population growth as a determinant of food demand in the economy.

$$
\begin{gathered}
D_{f}=\beta_{1}+\beta_{2} Y_{t}+\beta_{3} P_{f t}+\beta_{4} P_{n f t}+\beta_{5} T P_{I} \\
+\beta_{7} I P \ldots \ldots 4
\end{gathered}
$$

$T P_{t}$ is the numer of people food insecure people demanding food and IP is assumed exogenously determined outside the model. Moreover, the total population growth can be restated as the summation of food secured and unsecured people. i.e,

$$
\begin{aligned}
D_{f}=\beta_{1}+\beta_{2} Y_{t} & +\beta_{3} P_{f}+\beta_{4} P_{n f t} \\
& +\beta_{5}\left(F S P_{t}+N S P_{t}\right) \ldots .5
\end{aligned}
$$

The total amount of annual food aid provided to Ethiopia ranges from 200,000 to $1,200,000$ metric tons. The number of 'needy' Ethiopians between 1980 and 1995 ranged from 2.5 million (1987) to 7.85 million (1992), and in the current drought emergency 
it stands at 7.7 million. This statement states the fact that food demand is directly influenced by the number of food insecure people.

The market force of food demand and food supply determines the price of foods. By equating equation (4) and (5);

$$
\begin{gathered}
D_{f}=S_{f} \ldots \ldots \ldots \ldots \ldots \ldots \ldots . \cdots \\
\beta_{1}+\mu Y_{t}+\beta_{3} P_{f}+\beta_{4} P_{n f t}+\beta_{51} F S P_{t} \\
+\beta_{52} N S P_{t} \\
=\omega_{1} Y_{t}+\omega_{2} M_{t}+\omega_{3} P_{f t} \\
+\omega_{4} P_{n f t} \\
+\omega_{5} i d_{t} \ldots \ldots \ldots \ldots .9
\end{gathered}
$$

By rearranging; redefining some symbols

$$
\begin{array}{r}
\theta_{1}+\theta_{2} Y_{t}+\theta_{3} M_{t}+\theta_{4} P_{f t}+\theta_{5} P_{n f t} \\
+\theta_{6} \text { Aid }_{t}+\theta_{7} F S P_{t} \\
+\theta_{8} N S P_{t}=0
\end{array}
$$

The interdependence between these economic variables calls for a VAR model. The Bayesian VAR model has been employed to estimate the interdependence (mainly how food price change has an effect

on food insecurity rate). For $t=1,2 \ldots k$. The model and its reduced form with vectors is:

$$
\begin{gathered}
A_{0} y_{t}=A_{1} y_{t-1}+A_{2} y_{t-2}+\cdots+A_{k} y_{t-k}+ \\
D_{t} Z_{t}+\varepsilon_{t} \cdots \cdots \cdots \cdots(2)
\end{gathered}
$$

Suppose $A_{0} A^{-1}=B_{k}$, then, the final Bayesian VAR model in vector form can be stated as:

$$
\begin{aligned}
& y_{t}=B_{1} y_{t-1}+B_{2} y_{t-2}+\cdots+B_{k} y_{t-k}+D z_{t}+
\end{aligned}
$$

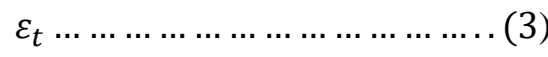

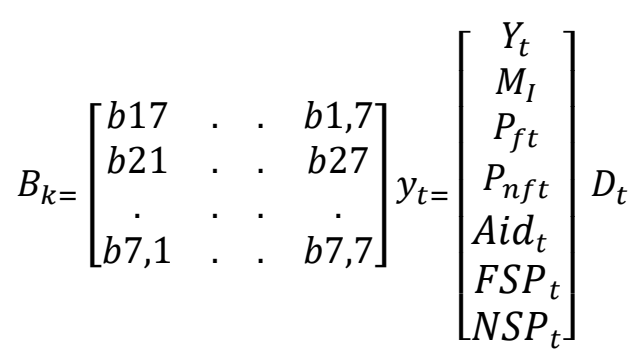

$$
\begin{aligned}
& =\left[\begin{array}{ccc}
d 11 & \cdot & d 14 \\
d 21 & \cdot & d 23 \\
\cdot & \cdot & \cdot \\
d 10 & \cdot & d 10,10
\end{array}\right] Z_{t=}\left[\begin{array}{c}
\text {Pins}_{t} \\
W_{t} \\
I P_{t}
\end{array}\right] \varepsilon_{t=}\left[\begin{array}{c}
e 11 \\
e 21 \\
\cdot \\
e 10,1
\end{array}\right]
\end{aligned}
$$

Where $N S P_{t}$ is food insecure people as a percentage of population, $F S P_{t}$ is the number of food secured people, $P_{f t}$ is the food inflation rate, $Y_{t}$ is total income, $P_{n f t}$ is the non-food price, $m_{t}$ is food imports and Faid $_{t}$ is food aid, $D_{t}$ is the vector of dummies (international food price (IP), climate change (W) and political instability (Pins) ), $E C_{t}$ is the error correction term, and $k$ is the appropriate lag length 


\subsection{Macro-Economic Data}

The model used seven endogenous variable and 3 exogenous variable with one hundred twenty- four quarterly observation. Annual time series data from 1988-2018 G. C was linearly interpolated in to a quarterly data with the help of Eviews software. All variables were transformed in to natural logarithms; and all variables except GDP percapita are in nominal terms. Food insecurity security variables were taken as the prevalence of undernourished as a percentage of total population whereas the food secured people the number of is and nourished people from the total population. Food and general price change enter the model using measurement of the quarterly growth rate of food price index and general price index respectively. The total food aid is the net aid growth received by the domestic economy from UN donor agencies. The nominal exchange rate as a measure of food import and availability of foreign exchange rate, and logarithm of quarterly percapita income measured by dividing real GDP by total population, logarithm of technology measured as crop production per hectare, are the other variables considered in the BVAR model. Growth rate of international price, political security and rain were entered the model as exogenous variables. Logarithm of world food price measured as China consumer price index, Logarithm of weather measured as rain fall distribution, and political security measured as value ranges from 1 up to 5 , where 1 stands for sever political instability.

\section{Results}

The paper analyzed the interdependence between food price inflation and the status of food insecurity in Ethiopia using a macroeconomic models. The macroeconomic model, the BVAR model, estimated after the selection of the required lag length using the AIC, SIC and the HQIC criteria. The BVAR estimated with seven variables with 2 lags of each exogenous variables (see appendix). To select the overall tightness prior $(\lambda)$, first a VAR which contain all exogenous variables was estimated with OLS to calculate the mean square error (MSE). Then after the value of $\lambda$ in the BVAR model which provide the same MSE with the VAR estimated with OLS was selected. Based on this $\lambda$ was set to 0.35 . The lag decay priors was set to be one and the cross-relative variable weight prior as set to 0.99 . The other prior is related to the AR (1) coefficient $(\delta)$ that determine in what extent the lag of each independent variable affects each dependent variable in the system. All variables used in the model was non- 
stationary or unit root exists. To support the effect of non-stationarity in the model, the value of $\delta=1$ was selected.

Table 1: Data Description

\begin{tabular}{|c|c|c|}
\hline Code & Description & Source \\
\hline $\log (\mathrm{NSP})$ & $\begin{array}{l}\text { Logarithm of the } \\
\text { percentage of } \\
\text { undernourished } \\
\text { people }\end{array}$ & WB \\
\hline $\log \left(P_{f t}\right)$ & $\begin{array}{l}\text { Quarterly food price } \\
\text { index }\end{array}$ & NBE \\
\hline $\log \left(Y_{t}\right)$ & $\begin{array}{l}\text { Logarithm of } \\
\text { percapita income }\end{array}$ & Author $^{2}$ \\
\hline $\log (E)$ & $\begin{array}{l}\text { Logarithm of } \\
\text { quarterly nominal } \\
\text { exchange rate }\end{array}$ & WB \\
\hline $\log (\mathrm{FSP})$ & $\begin{array}{l}\text { Logarithm of the } \\
\text { percentage of } \\
\text { nourished people }\end{array}$ & WB \\
\hline $\log \left(\operatorname{Pn}_{\mathrm{ft}}\right)$ & $\begin{array}{l}\text { Quarterly growth } \\
\text { rate of general price } \\
\text { index }\end{array}$ & WB \\
\hline $\begin{array}{l}(\log \\
\left.\left(\operatorname{Aid}_{t}\right)\right)\end{array}$ & $\begin{array}{l}\text { Natural logarithm of } \\
\text { Food aid }\end{array}$ & WB \\
\hline $\log \left(\mathrm{IP}_{\mathrm{t}}\right)$ & $\begin{array}{l}\text { Logarithm of world } \\
\text { food price }\end{array}$ & WB \\
\hline$\left(\log \left(W_{t}\right)\right)$ & $\begin{array}{l}\text { Logarithm of } \\
\text { weather measured }\end{array}$ & WB \\
\hline
\end{tabular}

\footnotetext{
${ }^{2}$ The author computed percapita income by dividing total GDP to total population data from the World Bank.
}

\begin{tabular}{|l|l|l|}
\hline & $\begin{array}{l}\text { as rain fall } \\
\text { distribution }\end{array}$ & \\
\hline Pins & $\begin{array}{l}\text { Political security: } \\
\text { value ranges from 1 }\end{array}$ & WGI \\
& up to 5 & \\
\hline
\end{tabular}

The analysis of the impulse response function is made based on the cholesky decomposition which follows a recursive exoginity assumption. The assumption states that the first variable in the VAR is contemporaneously explained by the shock itself alone; and the second variable in the VAR is contemporaneously affected by the shock in the first variable and the shock in itself, and so on. The table 6 in the appendix part displays the variance decomposition of the Bayesian VAR result of the specified model and the figure below presents the cholesky impulse responses of each variable in response to the other variables shocks. Figure 2 in the appendix part displays the impulse response of food insecurity to a cholesky one standard deviation shock to food price inflation, percapita income, general inflation rate, exchange rate, total food secured population and food aid. 
Our empirical finding show that a $1 \%$ shock to food price inflation, at macroeconomic level, leads to $0.1 \%$ decrease in the percentage change in food insecure people from the first and the second quarters. One of the reason may be a change in the price of food items (which are mainly agricultural products in Ethiopia) may benefit producers (members of the community live in rural areas mainly affected undernourishment) in the short term. In addition, it may be because of the reason that people use different short term coping mechanisms to protect themselves from hunger like food aid, NGO support, safety net programs, reducing the number of meals, forced engagement in productive activities to cope up with food inflation, and saving. Generally, the percentage of people under undernourishment reduces for four consecutive years. It means that the short term consequence of food price change is positive with food security (negative with food insecurity). Later the percentage reduction reduces and the percentage of undernourished people increase by $0.07 \%$ in the $6^{\text {th }}$ quarter. When peoples' saving is not enough to support their consumption, the rise in the price of food items would have a cost than a revenue for untarnished people, mainly people in the rural area who are engaging in agricultural production. The percentage of undernourished people increases up to the tenth quarter as a result of food price shock. It means that the long term consequence of food price change is negative with food security at macro level (positive with food insecurity).

The impulse response of percentage of food unsecured people are positive in response to a shock in real GDP growth. The positive response of the percentage of undernourished people continuously takes a positive value up to $15^{\text {th }}$ quarter. The impulse response of percentage of food undernourished people are positive and negative in response to a shock in the growth of the nominal exchange rate and food aid growth respectively. This response of continuously takes a positive and value throughout the whole quarter. The growth in the percentage of undernourished people reduces by $0.1 \%, 0.4 \%$ and $0.8 \%$ in the first, the second and the third quarters as a result of shock in the general price level. The finding shows that the higher the inflation rate, the lower the growth rate for percentage of undernourished people. However, starting from the $19^{\text {th }}$ quarter, the response in the percentage of undernourished people change in to positive. This tell us the positive effect of general inflation on the number of food insecure people are not 
immediate, even comparing with the food price inflation.

Comparing the negative and positive effect of food price change on food security, the short term has a great influence than the long term. It means that the positive term is greater than the negative term. When there is an increase in price of goods, the number of food insecure people reduces for the short term. But in the long term the effect will be reversed. But comparing the two, the speed by which the undernourished people decrease in number in the short term because of the inflation happened is higher than the speed by which the number of undernourished people increase in the long run at macro level.

\section{Conclusion}

The general objective of the study was to analyze food insecurity and food price inflation conditions at macro level. The study used a time series data for the macroeconomic analysis from the period 1988 quarter 1 to 2018 quarter four. In the Bayesian VAR model, it is assumed the food demand and food supply determines the price of goods and services. The model used seven endogenous variable and 3 exogenous variable with one hundred twenty eight quarterly observation.
Our empirical finding on the macroeconomic model show that a $1 \%$ shock to food price inflation leads to only $0.1 \%$ decrease in the percentage change in food insecure people from the first and the second quarters. One of the reason may be a change in the price of food items may benefit producers in the short term, the income may increase to compensate the rise inflation. In addition, may be because of the reason that people use different short term coping mechanisms to protect themselves from hunger like food aid, NGO support, safety net programs, reducing the number of meals per day, forced engagement in productive activities to cope up with food inflation, and saving. In addition to this, the food price inflation may be associate with the economic growth, as many studies suggests in Ethiopia. This economic growth, in turn, can reduce the percentage of undernourished people at macro level. Later the percentage reduction reduces and the percentage of undernourished people increase by $0.07 \%$ in the 6th quarter. The percentage of undernourished people increases up to the tenth quarter as a result of food price shock. The percentage of undernourished people increases up to the tenth quarter as a result of food price shock. The short term consequence of food price change is positive with food security (negative with food 
insecurity). The long term consequence of food price change is negative with food security (positive with food insecurity). From the variance decomposition, it can be learnt that the speed by which the undernourished people decrease in number in the short term because of the inflation happened is higher than the speed by which the number of undernourished people increase in the long run.

At macro level, concern should be made to the supply side for food security improvement. That is economic growth, nominal exchange rate and food aid and other external supports. Since these variables have a great influence on the level of food security.

\section{Reference}

Anderson et al., (2015), "USAID Office of Food for Peace Food Security Country Framework for Ethiopia FY 2016 - FY 2020". Washington, D.C.

Birhane et al. 2014. Urban food insecurity in the context of high food prices: a community based cross sectional study in Addis Ababa, Ethiopia. BMC Public Health, 14:680.

Central Statistics Authority (2009). Yearly publication. Addis Ababa

Central Statistical Agency (2016). Country and Regional Level Consumer Price Indices (CPI). Addis Ababa, Ethiopia.

Central Statistical Agency (2019). Country and Regional Level Consumer Price Indices (CPI). Addis Ababa, Ethiopia.
Cochrane, L., 2017. Strengthening food security in rural Ethiopia (Doctoral dissertation, University of British Columbia).

Cochrane, L. 2018. Food security in Ethiopia: Review of Research, 2005-2016. Ethiop.J.Appl.Sci. Technol. Vol.9 (1): 1 10(2018).

Denbel, F.S., Ayen, Y.W. and Regasa, T.A., (2016). The relationship between inflation, money supply and economic growth in Ethiopia: Co integration and Causality Analysis. International Journal of Scientific and Research Publications, 6(1), pp.556565.

Devereux, S. (2000). Food security in Ethiopia. A discussion paper for DFID. IDS Sussex.

Durevall, D.I.C.K., Loening, J. and Birru, Y., 2010. Inflation Dynamics and food prices inflation in Ethiopia (Vol. 478). University of Gothenburg working paper series.

Durevall, D., Loening, J.L. and Birru, Y.A., (2013). Inflation dynamics and food prices in Ethiopia. Journal of Development Economics, 104, pp.89-106.

Eric, A., Eduardo, S., \& Michael, A. (2018). Food inflation and household welfare: in the case of Ethiopia. African Journal of Agricultural Economics and Rural Development, 6(6), pp. 650-658.

Fischer, S., and Easterly, W., 2001. Inflation dynamics and food prices in Ethiopia. Journal of money,credit and Banking, Vol.33, No.2.

Food and Agricultural Organization (2015). "El Niño Response Plan 2016". Addis Ababa, Ethiopia.

Geda, A. and Tafere, K., 2008. The galloping inflation in Ethiopia: A cautionary tale for aspiring 'developmental states' in Africa. Department of Economics, AAU. 
Hadley, C and Freeman, MC. 2016. Assessing reliability, change after intervention, and performance of a water insecurity scale in rural Ethiopia. Food security 8: 855-864.

Maxwell, S. and Frankenberger, T. (1992). Household food security: concepts, indicators and measurements: a technical review. UNICEF and IFAD, New York and Rome.

Ministry of Agriculture and Rural Development (2009), "Ethiopian Food security program (2010- 2014)”. Final August 2009.

Moroda et al.: Food insecurity of rural households in Boset district of Ethiopia: a suite of indicators analysis. Agric \& Food Secur (2018) 7:65

Mulusew GJ, Mohammed T, Nakajima, M, Lemieux, A, Fikre L, Hoffman, R, Markos T, Tefera B, Netsanet W, Esayas K, Teklu G, Yinebeb T, Hailemariam S, Kolsteren, $\mathrm{P}$ andal'Absi, M. 2015.

\section{Appendix}

Table 2: The Bayesian VAR estimate of the model

Bayesian VAR Estimates

Date: 09/24/21 Time: 03:14

Sample (adjusted): 1988Q3 2018Q4

Included observations: 122 after adjustments

Prior type: Litterman/Minnesota

Initial residual covariance: Diagonal VAR

Hyper-parameters: Mu: 1, L1: 0.35, L2: 0.99, L3: 1

Standard errors in ( ) \& t-statistics in [ ]

\begin{tabular}{cccccccc}
\hline \hline & LOG(NSP) & LOG(PF) & LOG(Y) & LOG(E) & LOG(FSP) & LOG(PNF) & LOG(AID) \\
\hline \hline LOG(NSP(-1)) & 1.397649 & 0.063174 & 0.022775 & 0.085722 & -0.076795 & -0.127250 & -0.166281 \\
& $(0.09076)$ & $(0.14399)$ & $(0.05444)$ & $(0.10571)$ & $(0.05014)$ & $(0.08025)$ & $(0.29191)$ \\
& {$[15.3992]$} & {$[0.43872]$} & {$[0.41838]$} & {$[0.81094]$} & {$[-1.53156]$} & {$[-1.58571]$} & {$[-0.56962]$}
\end{tabular}

Samia, Z., Biratu, Y., Amit, W., \& McHarris, J. 2014. Comprehensive food security and vulnerability analysis: Ethiopia. CSA and World Bank collaborative program. Addis Ababa, Ethiopia.

Tefera B, Hadley, C, Lindstrom, D, Abebe G, Kifle WM, Yehenew G, Lachat, $C$ and Kolsteren, P. 2011b. Gender differences in food insecurity and morbidity amongadolescents in southwest Ethiopia. Pediatrics 127: e398-e405.

Watson, F, Bekele N, Dolan, C, Shoham, J and Hall, A. 2011. Quality and potential use of data collected duringnutrition surveys: an analysis of surveys in Ethiopia.International Health 3: 85-90.

World Bank (2012), "World Bank Support for Social Safety Net to Benefit 8.3 million Ethiopians by 2015". Press Release No: 2012/366/AFR. Washington, DC: World Bank.

World Bank (2018), World development Indicators. Excel spread sheet. 


\begin{tabular}{|c|c|c|c|c|c|c|c|}
\hline $\operatorname{LOG}(\operatorname{NSP}(-2))$ & $\begin{array}{r}-0.411499 \\
(0.09810) \\
{[-4.19474]}\end{array}$ & $\begin{array}{r}-0.091206 \\
(0.15560) \\
{[-0.58617]}\end{array}$ & $\begin{array}{r}-0.037703 \\
(0.05882) \\
{[-0.64098]}\end{array}$ & $\begin{array}{r}-0.054117 \\
(0.11422) \\
{[-0.47378]}\end{array}$ & $\begin{array}{c}0.118248 \\
(0.05418) \\
{[2.18234]}\end{array}$ & $\begin{array}{c}0.150956 \\
(0.08672) \\
{[1.74075]}\end{array}$ & $\begin{array}{r}0.490356 \\
(0.31544) \\
{[1.55453]}\end{array}$ \\
\hline $\operatorname{LOG}(\mathrm{PF}(-1))$ & $\begin{array}{r}-0.015131 \\
(0.04473) \\
{[-0.33825]}\end{array}$ & $\begin{array}{r}1.480353 \\
(0.07136) \\
{[20.7443]}\end{array}$ & $\begin{array}{c}-0.019538 \\
(0.02693) \\
{[-0.72564]}\end{array}$ & $\begin{array}{r}0.038356 \\
(0.05229) \\
{[0.73359]}\end{array}$ & $\begin{array}{c}0.008341 \\
(0.02477) \\
{[0.33677]}\end{array}$ & $\begin{array}{c}0.084285 \\
(0.03970) \\
{[2.12329]}\end{array}$ & $\begin{array}{r}0.223665 \\
(0.14439) \\
{[1.54905]}\end{array}$ \\
\hline $\operatorname{LOG}(\mathrm{PF}(-2))$ & $\begin{array}{r}0.115490 \\
(0.04835) \\
{[2.38854]}\end{array}$ & $\begin{array}{r}-0.514047 \\
(0.07715) \\
{[-6.66263]}\end{array}$ & $\begin{array}{r}-0.001296 \\
(0.02910) \\
{[-0.04453]}\end{array}$ & $\begin{array}{r}1.96 \mathrm{E}-05 \\
(0.05651) \\
{[0.00035]}\end{array}$ & $\begin{array}{r}-0.038388 \\
(0.02677) \\
{[-1.43396]}\end{array}$ & $\begin{array}{c}-0.005159 \\
(0.04290) \\
{[-0.12025]}\end{array}$ & $\begin{array}{r}-0.167744 \\
(0.15606) \\
{[-1.07487]}\end{array}$ \\
\hline $\operatorname{LOG}(\mathrm{Y}(-1))$ & $\begin{array}{r}-0.009462 \\
(0.10862) \\
{[-0.08711]}\end{array}$ & $\begin{array}{r}-0.007868 \\
(0.17293) \\
{[-0.04550]}\end{array}$ & $\begin{array}{r}1.522039 \\
(0.06549) \\
{[23.2403]}\end{array}$ & $\begin{array}{r}-0.344937 \\
(0.12695) \\
{[-2.71701]}\end{array}$ & $\begin{array}{r}-0.033302 \\
(0.06014) \\
{[-0.55373]}\end{array}$ & $\begin{array}{c}0.097151 \\
(0.09637) \\
{[1.00810]}\end{array}$ & $\begin{array}{r}0.188334 \\
(0.35067) \\
{[0.53707]}\end{array}$ \\
\hline LOG(Y(-2)) & $\begin{array}{r}0.044680 \\
(0.11088) \\
{[0.40297]}\end{array}$ & $\begin{array}{c}0.108114 \\
(0.17653) \\
{[0.61243]}\end{array}$ & $\begin{array}{r}-0.554737 \\
(0.06686) \\
{[-8.29739]}\end{array}$ & $\begin{array}{r}0.225794 \\
(0.12960) \\
{[1.74219]}\end{array}$ & $\begin{array}{r}0.010272 \\
(0.06139) \\
{[0.16732]}\end{array}$ & $\begin{array}{r}-0.075633 \\
(0.09838) \\
{[-0.76883]}\end{array}$ & $\begin{array}{r}-0.127038 \\
(0.35795) \\
{[-0.35491]}\end{array}$ \\
\hline $\operatorname{LOG}(\mathrm{E}(-1))$ & $\begin{array}{r}0.010884 \\
(0.06181) \\
{[0.17608]}\end{array}$ & $\begin{array}{c}0.184635 \\
(0.09842) \\
{[1.87607]}\end{array}$ & $\begin{array}{c}-0.015255 \\
(0.03721) \\
{[-0.40999]}\end{array}$ & $\begin{array}{r}1.467386 \\
(0.07239) \\
{[20.2696]}\end{array}$ & $\begin{array}{r}0.025251 \\
(0.03423) \\
{[0.73771]}\end{array}$ & $\begin{array}{c}-0.019125 \\
(0.05485) \\
{[-0.34871]}\end{array}$ & $\begin{array}{r}-0.253871 \\
(0.19954) \\
{[-1.27228]}\end{array}$ \\
\hline $\operatorname{LOG}(\mathrm{E}(-2))$ & $\begin{array}{r}0.022980 \\
(0.06098) \\
{[0.37686]}\end{array}$ & $\begin{array}{r}-0.199647 \\
(0.09709) \\
{[-2.05641]}\end{array}$ & $\begin{array}{c}0.018423 \\
(0.03671) \\
{[0.50191]}\end{array}$ & $\begin{array}{r}-0.529527 \\
(0.07142) \\
{[-7.41424]}\end{array}$ & $\begin{array}{r}-0.040877 \\
(0.03377) \\
{[-1.21056]}\end{array}$ & $\begin{array}{c}0.008869 \\
(0.05410) \\
{[0.16392]}\end{array}$ & $\begin{array}{r}0.237413 \\
(0.19684) \\
{[1.20610]}\end{array}$ \\
\hline $\operatorname{LOG}(\mathrm{FSP}(-1))$ & $\begin{array}{r}-0.198218 \\
(0.15484) \\
{[-1.28012]}\end{array}$ & $\begin{array}{c}0.237286 \\
(0.24615) \\
{[0.96399]}\end{array}$ & $\begin{array}{r}-0.098349 \\
(0.09306) \\
{[-1.05686]}\end{array}$ & $\begin{array}{r}0.101462 \\
(0.18072) \\
{[0.56143]}\end{array}$ & $\begin{array}{r}1.402302 \\
(0.08586) \\
{[16.3326]}\end{array}$ & $\begin{array}{c}0.024894 \\
(0.13719) \\
{[0.18146]}\end{array}$ & $\begin{array}{r}0.635211 \\
(0.49903) \\
{[1.27289]}\end{array}$ \\
\hline $\operatorname{LOG}(\mathrm{FSP}(-2))$ & $\begin{array}{r}0.272528 \\
(0.15638) \\
{[1.74268]}\end{array}$ & $\begin{array}{r}-0.169191 \\
(0.24856) \\
{[-0.68068]}\end{array}$ & $\begin{array}{c}0.086562 \\
(0.09397) \\
{[0.92118]}\end{array}$ & $\begin{array}{r}0.016112 \\
(0.18248) \\
{[0.08830]}\end{array}$ & $\begin{array}{r}-0.436542 \\
(0.08671) \\
{[-5.03459]}\end{array}$ & $\begin{array}{c}0.019813 \\
(0.13853) \\
{[0.14302]}\end{array}$ & $\begin{array}{r}-0.175298 \\
(0.50391) \\
{[-0.34788]}\end{array}$ \\
\hline $\mathrm{LOG}(\mathrm{PNF}(-1))$ & $\begin{array}{r}-0.203516 \\
(0.08177) \\
{[-2.48882]}\end{array}$ & $\begin{array}{r}-0.013883 \\
(0.13015) \\
{[-0.10667]}\end{array}$ & $\begin{array}{c}0.015975 \\
(0.04920) \\
{[0.32467]}\end{array}$ & $\begin{array}{r}-0.184929 \\
(0.09555) \\
{[-1.93547]}\end{array}$ & $\begin{array}{r}0.030109 \\
(0.04527) \\
{[0.66513]}\end{array}$ & $\begin{array}{c}1.399018 \\
(0.07267) \\
{[19.2529]}\end{array}$ & $\begin{array}{r}0.025387 \\
(0.26386) \\
{[0.09622]}\end{array}$ \\
\hline $\mathrm{LOG}(\mathrm{PNF}(-2))$ & $\begin{array}{r}0.042694 \\
(0.07890) \\
{[0.54109]}\end{array}$ & $\begin{array}{r}-0.048407 \\
(0.12561) \\
{[-0.38536]}\end{array}$ & $\begin{array}{c}0.011874 \\
(0.04748) \\
{[0.25005]}\end{array}$ & $\begin{array}{r}0.222882 \\
(0.09221) \\
{[2.41715]}\end{array}$ & $\begin{array}{r}0.044694 \\
(0.04369) \\
{[1.02302]}\end{array}$ & $\begin{array}{r}-0.512313 \\
(0.07014) \\
{[-7.30444]}\end{array}$ & $\begin{array}{r}-0.062742 \\
(0.25464) \\
{[-0.24639]}\end{array}$ \\
\hline $\operatorname{LOG}(\mathrm{AID}(-1))$ & $\begin{array}{r}-0.035842 \\
(0.02321) \\
{[-1.54431]}\end{array}$ & $\begin{array}{c}0.046595 \\
(0.03695) \\
{[1.26103]}\end{array}$ & $\begin{array}{r}-0.007163 \\
(0.01397) \\
{[-0.51275]}\end{array}$ & $\begin{array}{r}-0.019525 \\
(0.02713) \\
{[-0.71970]}\end{array}$ & $\begin{array}{r}0.016918 \\
(0.01285) \\
{[1.31657]}\end{array}$ & $\begin{array}{c}0.021775 \\
(0.02059) \\
{[1.05752]}\end{array}$ & $\begin{array}{r}1.383156 \\
(0.07505) \\
{[18.4289]}\end{array}$ \\
\hline $\operatorname{LOG}(\operatorname{AID}(-2))$ & $\begin{array}{r}0.015244 \\
(0.02225) \\
{[0.68516]}\end{array}$ & $\begin{array}{r}-0.037338 \\
(0.03542) \\
{[-1.05402]}\end{array}$ & $\begin{array}{r}0.024263 \\
(0.01339) \\
{[1.81144]}\end{array}$ & $\begin{array}{r}0.014830 \\
(0.02601) \\
{[0.57021]}\end{array}$ & $\begin{array}{r}-0.008309 \\
(0.01232) \\
{[-0.67446]}\end{array}$ & $\begin{array}{c}-0.019334 \\
(0.01974) \\
{[-0.97939]}\end{array}$ & $\begin{array}{r}-0.491587 \\
(0.07197) \\
{[-6.83092]}\end{array}$ \\
\hline
\end{tabular}




\begin{tabular}{lrrrrrrr}
\multicolumn{1}{c}{ C } & -1.001121 & -1.975391 & 0.084059 & -0.994160 & 0.460128 & -0.927691 & -5.735320 \\
& $(0.52152)$ & $(0.83035)$ & $(0.31387)$ & $(0.60950)$ & $(0.28875)$ & $(0.46268)$ & $(1.68329)$ \\
& {$[-1.91964]$} & {$[-2.37897]$} & {$[0.26781]$} & {$[-1.63111]$} & {$[1.59351]$} & {$[-2.00502]$} & {$[-3.40720]$} \\
LOG(IP) & -0.058598 & 0.046114 & 0.002139 & -0.043144 & 0.021647 & 0.010290 & -0.205433 \\
& $(0.02749)$ & $(0.04375)$ & $(0.01654)$ & $(0.03214)$ & $(0.01522)$ & $(0.02438)$ & $(0.08871)$ \\
& {$[-2.13197]$} & {$[1.05391]$} & {$[0.12929]$} & {$[-1.34249]$} & {$[1.42252]$} & {$[0.42199]$} & {$[-2.31582]$} \\
\multicolumn{1}{c}{ PINS } & 0.001568 & -0.001421 & 0.000685 & 0.003566 & -0.002734 & 0.002271 & 0.002037 \\
& $(0.00177)$ & $(0.00282)$ & $(0.00107)$ & $(0.00207)$ & $(0.00098)$ & $(0.00157)$ & $(0.00572)$ \\
& {$[0.88525]$} & {$[-0.50410]$} & {$[0.64252]$} & {$[1.72255]$} & {$[-2.78841]$} & {$[1.44538]$} & {$[0.35642]$} \\
\multicolumn{1}{c}{ LOG(W) } & -0.001458 & 0.004270 & 0.007472 & -0.002509 & 0.007418 & -0.017157 & 0.040862 \\
& $(0.00908)$ & $(0.01446)$ & $(0.00546)$ & $(0.01061)$ & $(0.00503)$ & $(0.00806)$ & $(0.02931)$ \\
& {$[-0.16059]$} & {$[0.29542]$} & {$[1.36736]$} & {$[-0.23640]$} & {$[1.47540]$} & {$[-2.12969]$} & {$[1.39427]$} \\
\hline \hline R-squared & 0.998587 & 0.999615 & 0.999699 & 0.999660 & 0.999780 & 0.999844 & 0.996757 \\
Adj. R-squared & 0.998356 & 0.999552 & 0.999650 & 0.999605 & 0.999744 & 0.999819 & 0.996226 \\
Sum sq. resids & 0.015322 & 0.039093 & 0.005530 & 0.021003 & 0.004646 & 0.012011 & 0.158958 \\
S.E. equation & 0.012138 & 0.019388 & 0.007292 & 0.014211 & 0.006684 & 0.010747 & 0.039095 \\
F-statistic & 4322.944 & 15886.63 & 20340.66 & 18008.67 & 27832.72 & 39320.00 & 1880.090 \\
Mean dependent & -0.982513 & 6.046211 & 8.318410 & 2.174895 & 17.59547 & 3.921906 & 19.44737 \\
S.D. dependent & 0.299348 & 0.916141 & 0.389864 & 0.714942 & 0.418020 & 0.798824 & 0.636431 \\
\hline \hline
\end{tabular}

Table 3: VAR Lag Length Specification of the Macroeconomic model

VAR Lag Order Selection Criteria

Endogenous variables: LOG(FINS) LOG(FOODP) LOG(YPERCAPITA) LOG(E) LOG(FSEC)

LOG(GDPDEF) LOG(FAID)

Exogenous variables: C LOG(WFPRICE) PINS LOG(RAIN)

Date: 09/23/21 Time: 14:17

Sample: 1988Q1 2018Q4

Included observations: 119

\begin{tabular}{ccccccc}
\hline \hline Lag & LogL & LR & FPE & AIC & SC & HQ \\
\hline \hline 0 & 811.4133 & NA & $4.51 \mathrm{e}-15$ & -13.16661 & -12.51270 & -12.90108 \\
1 & 2367.979 & 2825.362 & $4.49 \mathrm{e}-26$ & -38.50384 & -36.70559 & -37.77363 \\
2 & 2609.739 & 410.3837 & $1.78 \mathrm{e}-27$ & -41.74352 & $-38.80092^{*}$ & $-40.54862^{*}$ \\
3 & 2626.882 & 27.08208 & $3.13 \mathrm{e}-27$ & -41.20810 & -37.12115 & -39.54852 \\
4 & 2662.328 & 51.82834 & $4.13 \mathrm{e}-27$ & -40.98029 & -35.74900 & -38.85603 \\
5 & 2836.037 & $233.5589^{*}$ & $5.51 \mathrm{e}-28^{*}$ & $-43.07625^{*}$ & -36.70061 & -40.48731 \\
\hline \hline
\end{tabular}

* indicates lag order selected by the criterion

LR: sequential modified LR test statistic (each test at 5\% level)

FPE: Final prediction error

AIC: Akaike information criterion

SC: Schwarz information criterion

HQ: Hannan-Quinn information criterion 
Table 4: serial autocorrelation of the Macroeconomic model

VAR Residual Serial Correlation LM Tests

Null Hypothesis: no serial correlation at lag order $\mathrm{h}$

Date: 09/23/21 Time: 14:18

Sample: 1988Q1 2018Q4

Included observations: 122

\begin{tabular}{ccc}
\hline \hline Lags & LM-Stat & Prob \\
\hline \hline 1 & 58.82213 & 0.1589 \\
2 & 43.34066 & 0.7010 \\
\hline \hline
\end{tabular}

Probs from chi-square with $49 \mathrm{df}$.

Table 5: Impulse response of the Bayesian Vector Auto Regressive Model-table

\begin{tabular}{cccccccc} 
Period & LOG(FINS) & LOG(FOODP) & LOG(YPERCAPITA) & LOG(E) & LOG(FSEC) & LOG(GDPDEF) & LOG(FAID) \\
\hline \hline 1 & 0.012138 & 0.000000 & 0.000000 & 0.000000 & 0.000000 & 0.000000 & 0.000000 \\
2 & 0.018198 & -0.001068 & 0.000501 & 0.000142 & -0.000481 & -0.001896 & -0.001269 \\
3 & 0.021747 & -0.001311 & 0.001851 & 0.000905 & -0.000331 & -0.004990 & -0.003295 \\
4 & 0.023990 & -0.000808 & 0.003730 & 0.002466 & 0.000370 & -0.008731 & -0.005543 \\
5 & 0.025278 & $-1.24 \mathrm{E}-05$ & 0.005699 & 0.004659 & 0.001377 & -0.012668 & -0.007678 \\
6 & 0.025663 & 0.000710 & 0.007402 & 0.007177 & 0.002487 & -0.016409 & -0.009532 \\
7 & 0.025120 & 0.001165 & 0.008610 & 0.009714 & 0.003560 & -0.019623 & -0.011044 \\
8 & 0.023646 & 0.001291 & 0.009206 & 0.012026 & 0.004497 & -0.022052 & -0.012202 \\
9 & 0.021287 & 0.001118 & 0.009157 & 0.013941 & 0.005224 & -0.023517 & -0.013014 \\
10 & 0.018142 & 0.000718 & 0.008483 & 0.015350 & 0.005694 & -0.023924 & -0.013492 \\
11 & 0.014359 & 0.000185 & 0.007241 & 0.016195 & 0.005875 & -0.023258 & -0.013650 \\
12 & 0.010117 & -0.000385 & 0.005514 & 0.016458 & 0.005755 & -0.021573 & -0.013504 \\
13 & 0.005611 & -0.000905 & 0.003399 & 0.016148 & 0.005341 & -0.018980 & -0.013074 \\
14 & 0.001042 & -0.001300 & 0.001009 & 0.015303 & 0.004653 & -0.015637 & -0.012386 \\
15 & -0.003398 & -0.001516 & -0.001542 & 0.013977 & 0.003725 & -0.011730 & -0.011474 \\
16 & -0.007535 & -0.001517 & -0.004132 & 0.012241 & 0.002602 & -0.007463 & -0.010377 \\
17 & -0.011219 & -0.001288 & -0.006647 & 0.010178 & 0.001336 & -0.003047 & -0.009139 \\
18 & -0.014332 & -0.000838 & -0.008979 & 0.007876 & $-2.16 E-05$ & 0.001317 & -0.007807 \\
19 & -0.016788 & -0.000191 & -0.011033 & 0.005428 & -0.001415 & 0.005442 & -0.006430 \\
20 & -0.018540 & 0.000609 & -0.012729 & 0.002922 & -0.002796 & 0.009165 & -0.005053 \\
& & & & & & \\
\hline \hline
\end{tabular}

Figure 2: Impulse response of food insecurity to a shock for explanatory variables-graph 


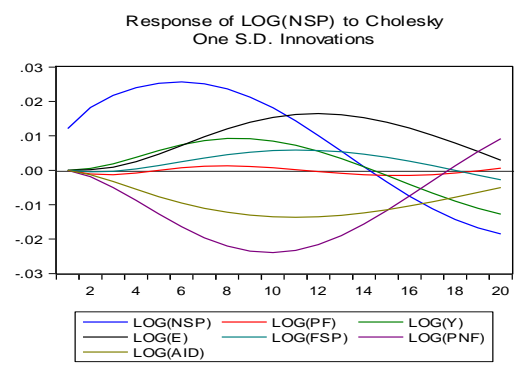

Response of LOG(E) to Cholesky One S.D. Innovations

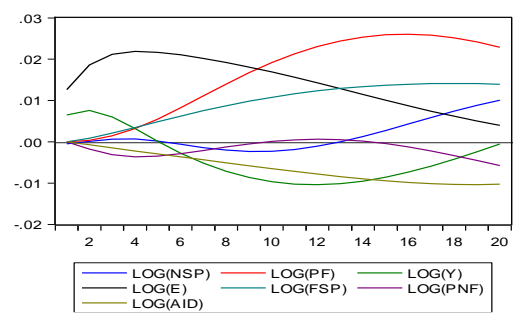

Response of LOG(PF) to Cholesky One S.D. Innovations

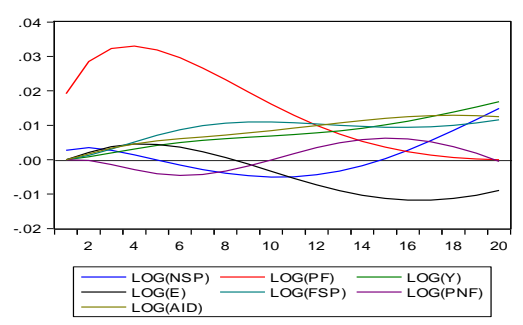

Response of LOG(FSP) to Cholesky One S.D. Innovations

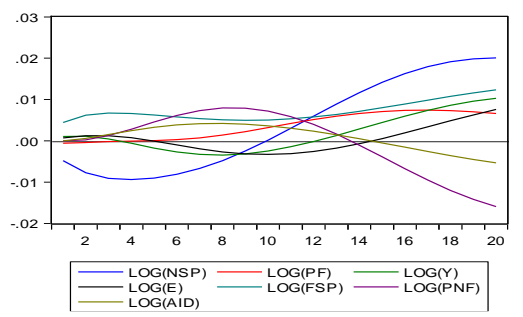

Response of $L O G(Y)$ to Cholesky One S.D. Innovations

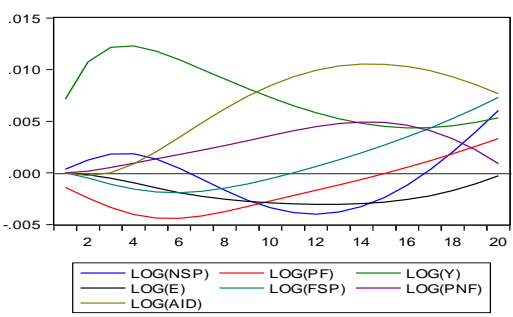

Response of LOG(PNF) to Cholesky

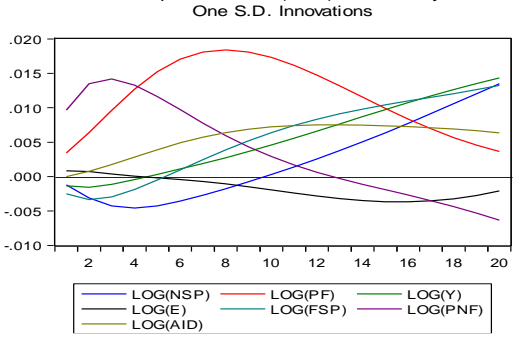

Table 6: Variance Decomposition of LOG (NSP)

\begin{tabular}{|c|c|c|c|c|c|c|c|c|}
\hline Period & S.E. & LOG(NSP) & LOG(PF) & LOG(Y) & LOG(E) & LOG(FSP) & LOG(PNF) & LOG(AID) \\
\hline 1 & 0.012138 & 100.0000 & 0.000000 & 0.000000 & 0.000000 & 0.000000 & 0.000000 & 0.000000 \\
\hline 2 & 0.022031 & 98.58889 & 0.234943 & 0.051715 & 0.004161 & 0.047713 & 0.740794 & 0.331782 \\
\hline 3 & 0.031624 & 95.13262 & 0.285925 & 0.367779 & 0.083981 & 0.034130 & 2.849120 & 1.246449 \\
\hline 4 & 0.041272 & 89.64249 & 0.206198 & 1.032875 & 0.406429 & 0.028076 & 6.148065 & 2.535866 \\
\hline 5 & 0.051165 & 82.73686 & 0.134173 & 1.912836 & 1.093696 & 0.090653 & 10.13005 & 3.901736 \\
\hline 6 & 0.061234 & 75.32982 & 0.107138 & 2.796721 & 2.137406 & 0.228284 & 14.25336 & 5.147269 \\
\hline 7 & 0.071205 & 68.15494 & 0.105989 & 3.530315 & 3.441940 & 0.418858 & 18.13573 & 6.212223 \\
\hline 8 & 0.080720 & 61.61527 & 0.108068 & 4.047848 & 4.898025 & 0.636248 & 21.57540 & 7.119138 \\
\hline 9 & 0.089432 & 55.86139 & 0.103665 & 4.346066 & 6.420256 & 0.859578 & 24.49165 & 7.917396 \\
\hline 10 & 0.097067 & 50.91168 & 0.093471 & 4.452948 & 7.950652 & 1.073734 & 26.86467 & 8.652844 \\
\hline 11 & 0.103464 & 46.73724 & 0.082591 & 4.409205 & 9.448147 & 1.267474 & 28.69871 & 9.356636 \\
\hline 12 & 0.108579 & 43.30562 & 0.076250 & 4.261438 & 10.87635 & 1.431823 & 30.00585 & 10.04266 \\
\hline 13 & 0.112489 & 40.59643 & 0.077511 & 4.061684 & 12.19418 & 1.559448 & 30.80323 & 10.70752 \\
\hline 14 & 0.115375 & 38.59923 & 0.086384 & 3.868691 & 13.35100 & 1.645043 & 31.11848 & 11.33117 \\
\hline 15 & 0.117499 & 37.29983 & 0.099937 & 3.747284 & 14.28754 & 1.686612 & 31.00003 & 11.87877 \\
\hline
\end{tabular}

